\title{
Prevalence and outcomes of breast milk expressing in women with healthy term infants: a systematic review
}

Helene M Johns ${ }^{1,2^{*}}$, Della A Forster ${ }^{1,2}$, Lisa H Amir ${ }^{1}$ and Helen L McLachlan ${ }^{1,3}$

\begin{abstract}
Background: Expressing breast milk has become increasingly prevalent, particularly in some developed countries. Concurrently, breast pumps have evolved to be more sophisticated and aesthetically appealing, adapted for domestic use, and have become more readily available. In the past, expressed breast milk feeding was predominantly for those infants who were premature, small or unwell; however it has become increasingly common for healthy term infants. The aim of this paper is to systematically explore the literature related to breast milk expressing by women who have healthy term infants, including the prevalence of breast milk expressing, reported reasons for, methods of, and outcomes related to, expressing.
\end{abstract}

Methods: Databases (Medline, CINAHL, JSTOR, ProQuest Central, PsycINFO, PubMed and the Cochrane library) were searched using the keywords milk expression, breast milk expression, breast milk pumping, prevalence, outcomes, statistics and data, with no limit on year of publication. Reference lists of identified papers were also examined. A hand-search was conducted at the Australian Breastfeeding Association Lactation Resource Centre. Only English language papers were included. All papers about expressing breast milk for healthy term infants were considered for inclusion, with a focus on the prevalence, methods, reasons for and outcomes of breast milk expression.

Results: A total of twenty two papers were relevant to breast milk expression, but only seven papers reported the prevalence and/or outcomes of expressing amongst mothers of well term infants; all of the identified papers were published between 1999 and 2012. Many were descriptive rather than analytical and some were commentaries which included calls for more research, more dialogue and clearer definitions of breastfeeding. While some studies found an association between expressing and the success and duration of breastfeeding, others found the opposite. In some cases these inconsistencies were compounded by imprecise definitions of breastfeeding and breast milk feeding.

Conclusions: There is limited evidence about the prevalence and outcomes of expressing breast milk amongst mothers of healthy term infants. The practice of expressing breast milk has increased along with the commercial availability of a range of infant feeding equipment. The reasons for expressing have become more complex while the outcomes, when they have been examined, are contradictory.

\footnotetext{
* Correspondence: h.johns@students.latrobe.edu.au

'Mother \& Child Health Research, La Trobe University, Melbourne, Victoria,

Australia

${ }^{2}$ Royal Women's Hospital, Parkville, Victoria, Australia

Full list of author information is available at the end of the article
} 


\section{Background}

Although data are collected about the proportion of women breastfeeding on discharge from hospital, little is known about how many women are expressing to provide breast milk feeds in addition to, or as an alternative, to feeding directly at the breast. There has been some discussion about increasing numbers of women in Australia, United States of America, the United Kingdom and Singapore expressing to give breast milk feeds rather than breastfeeding directly from the breast [1-6]. Only two studies, one conducted in Australia and one in Singapore $[2,6]$, measured expressing over time. Both reported an increase $[2,6]$.

From an historical point of view, Fildes' 1986 publication about the history of infant feeding provides a comprehensive insight into infant feeding practices from antiquity and describes related medical practices, popular customs and beliefs [7]. The 'drawing off' of breast milk was discussed by Avicenna (AD 980-1036) in the context of milk that was believed to be unpleasant smelling or too thick for the baby to drink [7]. Subsequent references to expressing describe the sucking glass, first mentioned in the mid-16th century $[7,8]$. The mother applied a glass cup to her breast and sucked on the end of its long glass stem to express milk when her nipples were cracked, or her breast inflamed or infected. During a time when there was concern about the undesirable effects of feeding colostrum to the newborn in preindustrial Europe, the sucking glass was used as an alternative to employing children or puppies to remove this early milk while the baby was fed by a wet nurse [7].

Developments in breast pump design and uptake over the last century are reflected in changes in 'brand' or company names during the same period. A collection at the Powerhouse Museum in Sydney, Australia includes the Breast Exhauster (1892), the Breast Reliever (1947), the more recent Kaneson hand pump (1973) [9] and the water operated Ellis Expressor (1970), locally designed to be connected to a kitchen tap [10]. By the early 1980s, breast pumps were transformed, as the red rubber tubing and glass apparatus and, in the case of the electric breast pump, the noisy motor, were substituted for more appealing designs. Pastel colours, discreet motors and less angular shapes became the norm and these pumps are now promoted with names that are arguably designed to enhance market acceptability. In addition to those mentioned in the previous paragraph, examples in name and design are seen in the earlier Lopuco and Egnell electric [11] and their successors, the Diana, Freestyle, Pump-in-style, Symphony, Swing, Harmony, Elite and Purely Yours pumps [12,13].

In the world of parenting print media, breast pumps have a growing advertising presence. A hand search of the catalogue of Essence, the bi-monthly member magazine of the Australian Breastfeeding Association (ABA) demonstrates a change in the focus of consumer discussion about breastfeeding over time. Breastfeeding is convenient, and advertising for breast pumps may be interpreted as suggesting that expressing is equally so. Blum writes of "the new regularized, fetishized breastfeeding . . . exemplified in the widespread advertising of pumps" [14] (p. 55). Breast milk expression appears to have become more popular as the associated equipment has become more sophisticated and readily available.

Many of the studies about expressing breast milk focus on premature and/or unwell infants [15-17] reflecting the main reasons women expressed to feed their infants in the past. It is likely that up until the last 20 years healthy term infants were either breastfed or bottle fed with infant formula. Although more recent literature has discussed the prevalence of breast milk expression and suggested that more women are expressing their milk $[1,5]$, measurement of this phenomenon is limited and the consequences relatively unknown.

Defining breastfeeding is complex. Discussion has previously focused on the accurate measurement of breast milk feeding; its exclusivity and duration [18]. That is, breastfeeding was the term used to describe any breast milk intake regardless of the mode of its delivery. The focus of recent debate has shifted and the emerging popularity of expressing presents another complexity; the need to find out how breast milk is given, directly at the breast, or otherwise [19]. In addition, Geraghty and Rasmussen have recommended a need to identify at what age the infant is exposed to expressed breast milk, and whose milk is being used [20].

In this paper expressing (also known as pumping) is used to describe using a pump to obtain breast milk, and hand expressing is used for instances where expressing is done by hand. Breastfeeding is used to describe the act of feeding directly from the breast, and breast milk feeding includes any means by which breast milk is given to the infant.

The aim of this paper is to systematically explore the literature related to breast milk expressing by women who have healthy term infants, including the prevalence of breast milk expressing, and the reported reasons for, methods of, and outcomes related to expressing.

\section{Methods}

The literature search for this paper included a search of Medline, CINAHL, JSTOR, ProQuest Central, PsycINFO, PubMed databases and the Cochrane library with no limit on the year of publication. Reference lists of identified papers were also examined. A hand search of consumer-focused breastfeeding newsletters was undertaken at the ABA Lactation Resource Centre in Melbourne, Australia which holds a collection of 
more than 18,000 documents related to human lactation. Relevant media and conference proceedings and personal communications were also searched. Only English language papers were included. Keywords used were: milk expression, breast milk expression, breast milk pumping, prevalence, outcomes, statistics and data. The date of the most recent electronic search was 26 February 2013.

Most of the articles identified in the search were specifically about expressing breast milk for sick and/or premature infants and therefore not relevant for this review, however these groups were included in the original search to ensure all relevant articles were located. A flowchart was developed according to PRISMA guidelines to summarise articles obtained in the literature search [21]. This tool is used to illustrate how many references have been located, the number of exclusions and the criteria for and number of eventual inclusions in the completed review.

All papers about expressing breast milk for healthy term infants were considered for inclusion. Papers about expressing that focused exclusively on premature infants were not included except where relevant for other aspects of this literature review (eg, Methods of expressing).

In the Results, the literature has been classified according to: prevalence of breast milk expressing, methods of expressing and reasons why women express. In addition outcomes and other implications of expressing are included. In each section the type and quality of papers identified is described and the papers are summarised and presented in tables under topic headings.

\section{Results}

A total of 22 papers identified were relevant to breast milk expression, but only seven papers reported the prevalence and/or outcomes of expressing amongst mothers of well term infants. Figure 1 provides a visual representation of the publications identified and reviewed [21]. All of the included papers were published subsequent to 1999. Many papers were descriptive rather than analytical and some were commentaries [22-24], including calls for more research, more dialogue and clearer definitions of infant feeding practice [20,22,25,26].

Included papers are summarised in tables, in chronological order, under the sub-headings:

- Prevalence of breast milk expressing;

- Methods of expressing;

- Reasons why women express their milk;

- Impact of expressing on breastfeeding outcomes;

- Other implications of expressing.

\section{Prevalence of breast milk expressing}

Seven papers were identified that reported on the prevalence of expressing amongst mothers of well, term infants. They came mainly from USA and Australia $[1-6,27]$. The papers vary in quality and design (Table 1 ).

Although several papers refer to an increase in the prevalence of expressing, the only data that actually documented such an increase were from Western Australia and Singapore $[2,6]$. The Perth Infant Feeding Study I (PIFS I), conducted in 1992-93 was followed by the Perth Infant Feeding Study II (PIFS II) ten years later [2]. Binns et al. reported the proportion of mothers

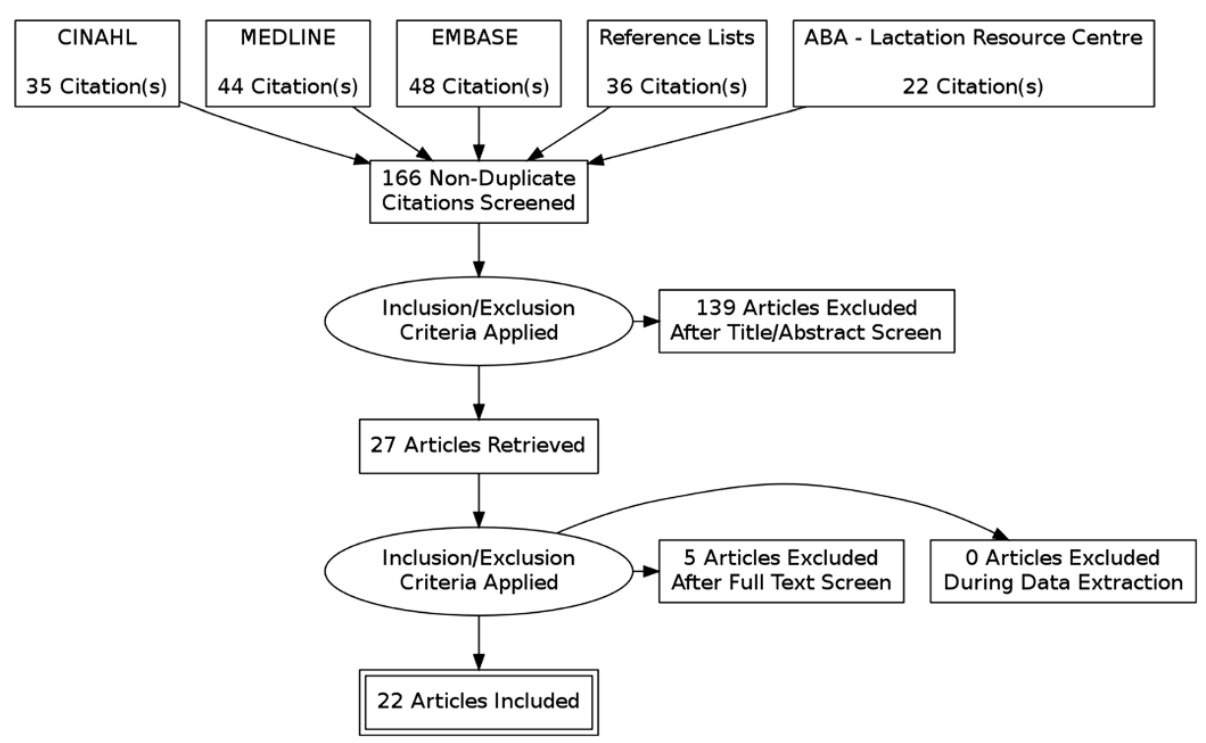

Figure 1 Database search. 
Table 1 Studies exploring prevalence of breast milk expressing

Author, year, Design Location, participants, year of

Author, year, Design Location, participants, year

Stud

Study aims and outcome

measures

Geraghty et al. Retrospective cohort

2005 USA [1]

Cincinnati, Ohio $n=3462002$

Random selection postal recruitment when infants were between

2 and 3 years old

Quan

Identify relationships between
breast pump use and

Perth, Western Australia

Binns et al. 2006 Australia [2]

Labiner-Wolfe et al. Longitudinal 2008 USA [3]

PIFS I $n=556 \quad \begin{aligned} & \text { - Measure and compare } \\ & \text { prevalence of expressing }\end{aligned}$

1992-93

PIFS II $n=587$

2002-03

Recruited in hospital in early postpartum period

National study

$n=4606$
- singleton vs. multiple pregnancy

- gestation at birth

- breastfeeding outcomes

\section{Results}

77\% (182/236) ever used

breast pump

No significant difference in

of mothers; those of

- term singletons

- preterm singletons

- term multiples

- preterm multiples

- 68\% (236/346) received at

least some breast milk.

- 5\% (12/236) exclusively

expressed to feed - all mothers

of premature babies

- PIFS I 38\% (211/556)

- PIFS I| 69\% (405/587)

expressing by 4 weeks

- Expressing rates steadily decline after 6 weeks:

$26 \%(145 / 556)$ at 24 weeks in PIFS I 28\% (164/587) at 22 weeks in PIFS I|

Reasons why women express

- Most common reason: for someone else to feed baby

- Amount and prevalence of milk expression

- 85\% (1329/1564) between expressing between 4 groups

Strengths/Limitations

Large sample size

Clear differentiation between breastfeeding and breast milk feeding

Periodic reports re. proportion of expressing versus breastfeeding (at 1 day, 3 days, 2 weeks and monthly until 6 months)

Retrospective data, possible recall bias, initial

contact made when children between 2-3 years of age-requesting detailed information about infant feeding at 24 hrs, 3 days, 2 weeks and then at monthly intervals to 6 months.

Expressing methods not distinguished between hand, manual or electric pump

1.5 and 4.5 months postpartum

had expressed at some time

since birth
Large sample

Comparison of similar groups 10 years apart

Limited detail about expressed breast milk breastfeeding proportions.

Public patients only, perhaps not representative

Differing interview schedules - less clarity for comparison

Large sample

Maternal recall previous 7 days 
Table 1 Studies exploring prevalence of breast milk expressing (Continued)

\begin{tabular}{|c|c|c|c|c|c|}
\hline & & 2005-2007 & $\begin{array}{l}\text { - Associated socio-demographic } \\
\text { factors }\end{array}$ & $\begin{array}{l}\text { - } 68 \%(1015 / 1493) \text { of this group } \\
\text { had expressed in } 2 \text { weeks before } \\
\text { survey, } 25 \%(373 / 1493) \text { regularly }\end{array}$ & $\begin{array}{l}\text { Measures frequency of expressing (asked ho } \\
\text { many times expressed in previous } 2 \text { weeks } \\
\text { if expressed on a regular schedule) }\end{array}$ \\
\hline & & from IFPS ॥ & & $\begin{array}{l}\text { - Expressing associated with: } \\
\text { maternal employment, higher } \\
\text { income, first breastfeeding } \\
\text { experience }\end{array}$ & $\begin{array}{l}\text { Not nationally representative: Older, more } \\
\text { educated, more likely to be white, employed, } \\
\text { higher income, less likely to smoke. More } \\
\text { likely to breastfeed and for longer }\end{array}$ \\
\hline & & $\begin{array}{l}\text { Mail survey } 2,5 \text { and } 7 \\
\text { months postpartum }\end{array}$ & & & \\
\hline \multirow[t]{5}{*}{$\begin{array}{l}\text { Shealy et al. } 2008 \\
\text { USA [4] }\end{array}$} & Longitudinal & National study & $\begin{array}{l}\text { Describe breastfeeding in first } \\
12 \text { months to identify: }\end{array}$ & $\begin{array}{l}-0.06 \% \text { of babies fed expressed } \\
\text { breast milk exclusively }-2 / 3 \text { of } \\
\text { these ceased breast milk feeding } \\
\text { by } 4 \text { weeks }\end{array}$ & $\begin{array}{l}\text { Detailed analysis of feeding type/ } \\
\text { frequency/duration of individual feeds }\end{array}$ \\
\hline & & $n=2587$ & $\begin{array}{l}\text { - Prevalence of exclusive pumping } \\
\text { and formula supplementing }\end{array}$ & & $\begin{array}{l}\text { Limited data re. expressing - except } \\
\text { when it was exclusive }\end{array}$ \\
\hline & & 2005-2007 & $\begin{array}{l}\text { - Patterns and trends in } \\
\text { breastfeeding related to common } \\
\text { advice given }\end{array}$ & & \\
\hline & & from IFPS II & & & \\
\hline & & Monthly postal questionnaires & & & \\
\hline \multirow[t]{5}{*}{$\begin{array}{l}\text { Clemons \& Amir } \\
2010 \text { Australia [5] }\end{array}$} & Cross-sectional & State-wide study, Victoria & $\begin{array}{l}\text { - Prevalence of breast milk } \\
\text { expression }\end{array}$ & $\begin{array}{l}\text { - } 67 \%(602 / 898) \text { had fully breastfed } \\
\text { prior to hospital discharge }\end{array}$ & Large study \\
\hline & & $n=903$ & $\begin{array}{l}\text { - Demographic characteristics } \\
\text { of women who express, why } \\
\text { and how they do it }\end{array}$ & $\begin{array}{l}\text { - 14\% (125/898) had breastfed and } \\
\text { expressed to feed their baby }\end{array}$ & $\begin{array}{l}\text { Possible selection bias (members of the } \\
\text { Australian Breastfeeding Association) }\end{array}$ \\
\hline & & 2008 & $\begin{array}{l}\text { - Women's experience of using } \\
\text { breast pumps }\end{array}$ & $\begin{array}{l}\text { - Of those whose youngest child } \\
\text { was over six months } 95 \%(628 / 661) \\
\text { fully breastfed for at least six months }\end{array}$ & Timing of questionnaire, possible recall bias \\
\hline & & $\begin{array}{l}\text { Online questionnaire sent to } \\
\text { Australian Breastfeeding Association } \\
\text { members who had an email address }\end{array}$ & & $\begin{array}{l}\text { - } 4 \% \text { (34/898) expressed and } \\
\text { exclusively fed EBM }\end{array}$ & \\
\hline & & Baby any age & & - 98\% (885/903) ever expressed & \\
\hline \multirow[t]{3}{*}{$\begin{array}{l}\text { Hornbeak et al. } \\
2010 \text { Singapore [6] }\end{array}$} & Retrospective cohort & Singapore & $\begin{array}{l}\text { - Prevalence and patterns of } \\
\text { breastfeeding in Singaporean } \\
\text { Chinese mothers from birth } \\
\text { to } 6 \text { months }\end{array}$ & $\begin{array}{l}\text { - Initiation of breast milk feeding } \\
\text { increased from } 69 \%(144 / 210) \text { in } \\
2000-2001 \text { to } 82 \%(538 / 656) \text { in } \\
2006 / 2008\end{array}$ & $\begin{array}{l}\text { Large representative sample of Chinese } \\
\text { Singaporean mothers }\end{array}$ \\
\hline & & $n=3009$ & & $\begin{array}{l}\text { - Exclusive expressing increased } \\
\text { from } 9 \%(18 / 144) \text { in 2000-2001 to } \\
18 \%(118 / 538) \text { in 2006/2008 }\end{array}$ & $\begin{array}{l}\text { Limited detail about expressed breast milk/ } \\
\text { breastfeeding proportions. }\end{array}$ \\
\hline & & $2006-2008$ & & $\begin{array}{l}\text { - Direct breast milk feeding } \\
\text { decreased from } 34 \%(72 / 210) \\
\text { in 2000-2001 to } 27 \%(142 / 656) \\
\text { in 2006/2008 }\end{array}$ & $\begin{array}{l}\text { Possible recall bias - recruitment } \\
6-72 \text { months after birth }\end{array}$ \\
\hline
\end{tabular}




\begin{tabular}{|c|c|c|c|c|c|}
\hline & & $\begin{array}{l}\text { Recruited mothers of 6-72 month } \\
\text { Chinese Singaporean children } \\
\text { through Strabismus, Amblyopia and } \\
\text { Refractive Error in Singaporean } \\
\text { Children (STARS) Study }\end{array}$ & & & Gestational age not indicated \\
\hline & & Mailed invitation & & & \\
\hline & & Face-to-face interview & & & \\
\hline \multirow[t]{7}{*}{$\begin{array}{l}\text { Geraghty et al. } \\
2012 \text { USA [29] }\end{array}$} & $\begin{array}{l}\text { Prospective longitudinal } \\
\text { cohort }\end{array}$ & Cincinnati, Ohio & $\begin{array}{l}\text { - Describe who commences } \\
\text { expressing early }\end{array}$ & $\begin{array}{l}\text { - } 14 \%(8 / 59) \text { commenced some } \\
\text { expressing in first week }\end{array}$ & Prospective design assisting recall \\
\hline & & $n=60$ & $\begin{array}{l}\text { - Explore breastfeeding duration } \\
\text { in women who express }\end{array}$ & $\begin{array}{l}\text { - By four weeks: 63\% } \\
\text { (37/59) expressing }\end{array}$ & $\begin{array}{l}\text { Initial weekly visits; used weekly and } \\
24 \text { hour recall to enquire about } \\
\text { feeding and expressing }\end{array}$ \\
\hline & & 2004-2007 & & $\begin{array}{l}\text { - Expressing had no effect on } \\
\text { duration of breast milk feeding }\end{array}$ & $\begin{array}{l}\text { Clear differentiation between } \\
\text { 'breastfeeding' and 'breast milk feeding' }\end{array}$ \\
\hline & & $\begin{array}{l}\text { Recruited face to face in first } \\
\text { week after hospital discharge. }\end{array}$ & & & Small study \\
\hline & & & & & $\begin{array}{l}\text { Recruitment of women who planned to } \\
\text { breastfeed for } 6 \text { months or more }\end{array}$ \\
\hline & & & & & $\begin{array}{l}\text { Mothers recruited for study knew they were going } \\
\text { to be assisted to pump and may have been more } \\
\text { likely to be comfortable with this. }\end{array}$ \\
\hline & & & & & $\begin{array}{l}\text { Possible introduction of bias as weekly collection } \\
\text { of breast milk was initiated at } 1 \text { week by research } \\
\text { nurse using an electric breast pump }\end{array}$ \\
\hline
\end{tabular}


who expressed breast milk (not necessarily expressing exclusively) during the first six weeks after birth, and found a $31 \%$ increase over ten years as well as a gradual decline in expressing after the first six weeks [2]. (The Singapore study reports exclusive expressing and is discussed below [6]).

In Mid-Western USA in 2002, Geraghty et al. found only sixteen percent (55/346) of women breastfed exclusively at the breast for the duration of their lactation and just seven percent $(24 / 346)$ of the same group breastfed exclusively at the breast for a minimum of six months [1]. The authors concluded that expressing had become an integral part of human milk feeding [1]. Also in the USA, Labiner-Wolfe et al. analysed data from the Infant Feeding Practices Study II (IFPS II) (collected between 2005 and 2007), and found that 85\% (1329/1564) of breastfeeding women had expressed breast milk, and that of these women, more than half had done so in the first week after birth [3]. An online study in Victoria, Australia found that 98\% (885/903) of breastfeeding women had expressed at some time [5], however, this was a very select group - as respondents were all members of the ABA.

A small proportion of women never breastfeed, but rather exclusively breast milk feed using expressed breast milk. Geraghty et al. reported that five percent of women exclusively expressed and fed breast milk, all of whom were mothers of premature infants [1]. Another study in the USA identified a six percent exclusive expressing rate amongst infants between 35 and 45 weeks gestation [4]. In Australia, Clemons and Amir found that four percent of women in their cross-sectional study expressed exclusively [5]. In comparison, the exclusive expressing group was higher in Singapore; increasing from nine to eighteen percent between 2000-01 and 2006-08, apparently at the expense of direct breastfeeding which decreased from 34 to 22 percent over the same time period [6].

\section{Methods of expressing}

A Cochrane review, which included 23 studies assessing breast milk expression methods found that there was no difference between manual and electric pumps in terms of breast milk production [28]. Most of the studies in the systematic review were excluded from this review because they did not meet inclusion criteria, mainly because they focused on premature or unwell infants. The papers discussed in this section are described in Table 2.

Given its universal accessibility, the simplest way to express milk is by hand, and evidence from a Japanese study demonstrates that this is the most effective method to use when expressing colostrum [29]. Hand expressing however, was associated with increased reports of local pain compared to electric breast pumping [29]. A randomised trial in the USA which compared hand expressing and pump use found that early hand expression appeared to improve breastfeeding rates at two months when compared with using a pump [30].

Although hand expression may be just as effective [28], and electric breast pumps are considerably more expensive than simple hand expression or the use of a hand operated pump, the use of electric breast pumps has become more popular over the last decade [31], and in Perth, Australia, has increased threefold in ten years [2]. Electric breast pumps are a regular feature of postnatal wards of maternity hospitals in Washington, DC where Buckley, examining the views of lactation consultants about breast pumps, writes about the prominence of the breast pump, evidenced by the universality of its provision, in her words, "A breast pump for every room" [31] (p.16). The accessibility of electric breast pumps is demonstrated in an online study in Australia which found that $66 \%(556 / 843)$ of breastfeeding women had used an electric breast pump [5]. In a mail survey of 3,606 women from the IFPS II in the USA, women who undertook regular scheduled expressing were more likely to use electric breast pumps [3].

\section{Reasons why women express their milk}

Factors that appear to be associated with women's decisions to express their breast milk have been reported in some papers (Table 3). Women who experience difficulty establishing breastfeeding are more likely to express $[2,3,5,27]$, and mothers with premature or low birth weight infants, mothers who are unwell, those who have not previously breastfed are also more likely to express [5,27].

Women with an elevated body mass index (BMI) are more likely to express their milk than to breastfeed, perhaps related to anxiety about exposing their bodies $[27,32]$. Obese women often have large breasts and may experience difficulty feeding discretely [33]. In addition these women may express because of physical difficulty with breastfeeding. Large breast size may impede maternal ability to see and or facilitate appropriate infant attachment and feeding [33]. Leonard et al. investigated breast milk expressing behaviours and concluded that expressing may support longer durations of breastfeeding in overweight or obese women [32]. Embarrassment about breastfeeding in public has been identified as a reason women express regardless of cultural background or body size $[5,34,35]$. Cultural differences may inhibit women from breastfeeding outside the home, leading to some women expressing so that they can avoid exposing their bodies in public [3,5,34].

Other reasons women express include breastfeeding problems such as mastitis and breast engorgement [2]; nipple pain and difficulty with attachment to the breast [5]; concern about oversupply or undersupply $[3,5,34,36]$ 
Table 2 Studies exploring methods of expressing

\begin{tabular}{|c|c|c|c|c|c|}
\hline $\begin{array}{l}\text { Author, year, } \\
\text { country }\end{array}$ & Design & $\begin{array}{l}\text { Location, participants, year of study } \\
\text { and recruitment }\end{array}$ & Study aims and outcome measures & Results & Strengths/Limitations \\
\hline \multirow[t]{6}{*}{$\begin{array}{l}\text { Binns et al. } 2006 \\
\text { Australia [2] }\end{array}$} & \multirow[t]{6}{*}{ Longitudinal } & Perth, Western Australia & - Explore determinants of breastfeeding & $\begin{array}{l}\text { - Approx. } 60 \%(n=1143) \text { using } \\
\text { manual pumps in both studies }\end{array}$ & Large study \\
\hline & & PIFS I n = 556 & $\begin{array}{l}\text { - Measure and compare prevalence of } \\
\text { expressing 1992-93 and 2002-03 }\end{array}$ & $\begin{array}{l}\text { - Use of electric pumps increased } \\
\text { by } 31 \% \text { in } 10 \text { years }\end{array}$ & $\begin{array}{l}\text { Comparison of similar groups } \\
10 \text { years apart }\end{array}$ \\
\hline & & 1992-93 & & & Actual figures not given \\
\hline & & PIFS $\| n=587$ & & & $\begin{array}{l}\text { Public patients only, perhaps } \\
\text { not representative }\end{array}$ \\
\hline & & $2002-03$ & & & \\
\hline & & $\begin{array}{l}\text { Recruited in hospital in early } \\
\text { post-partum period }\end{array}$ & & & \\
\hline \multirow{4}{*}{$\begin{array}{l}\text { Labiner-Wolfe et al. } \\
2008 \text { USA [3] }\end{array}$} & \multirow[t]{4}{*}{ Longitudinal } & National study & - Reasons why women express & - Birth to $1.5-4.5$ months & Large sample size \\
\hline & & $n=4606$ & - Amount and prevalence of milk expression & $\begin{array}{l}80 \%(105 / 1302) \text { battery or electric } \\
44 \%(573 / 1302) \text { manual pump } \\
14 \%(18 / 1302) \text { hand }\end{array}$ & $\begin{array}{l}3 \text { mailed questionnaires seeking } \\
\text { information re. feeding in previous } \\
\text { fortnight - recall bias unlikely }\end{array}$ \\
\hline & & 2005-2007 IFPS II & - Associated socio-demographic factors & $\begin{array}{l}\text { - Previous } 3 \text { months to } \\
6.5-9.5 \text { months }\end{array}$ & $\begin{array}{l}\text { Detailed information re. methods } \\
\text { of expression over time }\end{array}$ \\
\hline & & $\begin{array}{l}\text { Mail survey } 2,5 \text { and } 7 \\
\text { months postpartum }\end{array}$ & & $\begin{array}{l}73 \%(39 / 529) \text { battery or electric) } \\
33 \%(18 / 529) \text { manual pump 13\% } \\
(69 / 529) \text { hand }\end{array}$ & $\begin{array}{l}\text { Not nationally representative, older, } \\
\text { more educated, more likely to be } \\
\text { white, employed, higher income, } \\
\text { less likely to smoke. More likely to } \\
\text { breastfeed and for longer }\end{array}$ \\
\hline \multirow[t]{4}{*}{$\begin{array}{l}\text { Ohyama et al } 2010 \\
\text { Japan [31] }\end{array}$} & \multirow[t]{4}{*}{$\begin{array}{l}\text { Sequential } \\
\text { crossover }\end{array}$} & Yokohama, Kanagawa & $\begin{array}{l}\text { - Comparison of effectiveness and comfort } \\
\text { of manual and electric breast expression } \\
\text { in first } 48 \text { hours after birth }\end{array}$ & $\begin{array}{l}\text { - Manual expressing associated } \\
\text { with greater milk volume: net milk } \\
\text { yield per woman } 2 \mathrm{ml} \text {. }\end{array}$ & $\begin{array}{l}\text { Limited other exploration } \\
\text { of this area }\end{array}$ \\
\hline & & $\mathrm{n}=11$ & & $\begin{array}{l}\text { - Manual expression } 2 \mathrm{ml} \text { (median; } \\
\text { range: 0-12.6 ml.) }\end{array}$ & Small study \\
\hline & & 2003-2004 & & $\begin{array}{l}\text { - Electric expression } 0.6 \mathrm{ml} \\
(0-7.2 \mathrm{ml} .)(P<0.05)\end{array}$ & $\begin{array}{l}\text { Infant gestation and health status } \\
\text { not indicated }\end{array}$ \\
\hline & & $\begin{array}{l}\text { Mothers of infants admitted to } \\
\text { neonatal intensive care recruited } \\
\text { in hospital soon after birth }\end{array}$ & & $\begin{array}{l}\text { - Manual pump associated with } \\
\text { more reports of pain }\end{array}$ & \\
\hline \multirow[t]{3}{*}{$\begin{array}{l}\text { Flaherman et al } \\
2012 \text { USA [32] }\end{array}$} & \multirow[t]{3}{*}{ RCT } & San Francisco \& Sacramento, California & $\begin{array}{l}\text { Comparison of hand and electric } \\
\text { expression measured; }\end{array}$ & $\begin{array}{l}\text { - At } 2 \text { months mothers assigned to } \\
\text { hand expressing were more likely to } \\
\text { be breastfeeding ( } 97 \% \text {, } 47 / 48 \text { ) than } \\
\text { mothers assigned to breast pumping } \\
\text { (73\%,35/48) (RR:1.32, } 95 \% \text { Cl } 1.01,1.73 \text { ) }\end{array}$ & $\begin{array}{l}\text { Limited other exploration of this } \\
\text { area, no previous studies linking } \\
\text { type of expressing to } \\
\text { breastfeeding outcomes }\end{array}$ \\
\hline & & $n=68$ & - Milk transfer & & Thorough discussion \\
\hline & & 2007-2009 & - Breast pain & & $\begin{array}{l}\text { Small study, final outcome assessment } \\
\text { based on } 48 \text { participants }\end{array}$ \\
\hline
\end{tabular}




\begin{tabular}{|c|c|c|c|c|c|}
\hline \multirow[t]{2}{*}{$\begin{array}{l}\text { Becker et al. } 2011 \\
\text { UK [30] }\end{array}$} & $\begin{array}{l}\text { Systematic } \\
\text { review }\end{array}$ & International & $\begin{array}{l}\text { - Assessment and review of randomised } \\
\text { and quasi randomised trials comparing } \\
\text { methods of milk expression any time after } \\
\text { birth and crossover trials commencing at } \\
\text { least } 28 \text { days after birth }\end{array}$ & - More milk with relaxation tape & Systematic review \\
\hline & & $\mathrm{n}=642$ women from 23 studies & & $\begin{array}{l}\text { - No difference in mean vol. with } \\
\text { simultaneous or sequential pumping, } \\
\text { or between manual and electric } \\
\text { pumps studied }\end{array}$ & $\begin{array}{l}\text { Most studies specifically related to } \\
\text { the care of the pre-term infant }\end{array}$ \\
\hline
\end{tabular}

- Breast milk expression experience

Possible bias- recruited infants

No control group

\section{Breastfeeding rates at 2 month}

sment and review of randomised

-

pumps studied 
Table 3 Studies exploring reasons women express

\begin{tabular}{|c|c|c|c|c|c|}
\hline $\begin{array}{l}\text { Author, year, } \\
\text { country }\end{array}$ & Design & $\begin{array}{l}\text { Location, participants, year of } \\
\text { study and recruitment }\end{array}$ & $\begin{array}{l}\text { Study aims and outcome } \\
\text { measures }\end{array}$ & Results & Strengths/Limitations \\
\hline \multirow[t]{4}{*}{$\begin{array}{l}\text { Dykes \& Williams } \\
1999 \text { UK [34] }\end{array}$} & $\begin{array}{l}\text { Longitudinal, } \\
\text { phenomenological study }\end{array}$ & Northern England, & $\begin{array}{l}\text { - Explore women's experience of } \\
\text { expressing particularly perception } \\
\text { of adequacy of milk supply }\end{array}$ & $\begin{array}{l}\text { - Beliefs re. adequacy of breast milk } \\
\text { supply influenced by interplay of feeding } \\
\text { management, infant behaviour, lactation } \\
\text { physiology and maternal mental health. }\end{array}$ & Small mono-cultural group \\
\hline & & $n=10$ & & & \\
\hline & & 1998 & & & \\
\hline & & $\begin{array}{l}\text { Postnatal primiparas recruited } \\
\text { face-to-face in hospital, home } \\
\text { visits at } 6,8 \& 12 \text { weeks }\end{array}$ & & & \\
\hline \multirow[t]{9}{*}{$\begin{array}{l}\text { Binns et al. } 2006 \\
\text { Australia [2] }\end{array}$} & Longitudinal cohort & Perth, Western Australia & $\begin{array}{l}\text { - Explore determinants of } \\
\text { breastfeeding }\end{array}$ & - Early breastfeeding difficulties, & $\begin{array}{l}\text { Comparison of similar groups } \\
10 \text { years apart }\end{array}$ \\
\hline & & PIFS I $n=556$ & $\begin{array}{l}\text { - Measure and compare prevalence } \\
\text { in expressing }\end{array}$ & - Engorgement, sore nipples, mastitis & $\begin{array}{l}\text { Mainly women who expressed to } \\
\text { manage breastfeeding difficulties }\end{array}$ \\
\hline & & 1992-93 & & - Feed to be given by someone else & $\begin{array}{l}\text { Public patients only, perhaps not } \\
\text { representative }\end{array}$ \\
\hline & & PIFS $\| n=587$ & & - To store extra milk & \\
\hline & & $2002-03$ & & - Father to feed & \\
\hline & & $\begin{array}{l}\text { Recruited in hospital in early } \\
\text { post-partum period. }\end{array}$ & & - To increase supply & \\
\hline & & & & - Feeding/attachment problems & \\
\hline & & & & - To get baby to drink from a bottle & \\
\hline & & & & - Just to try it out & \\
\hline \multirow{6}{*}{$\begin{array}{l}\text { Labiner-Wolfe et al. } \\
2008 \text { USA [3] }\end{array}$} & Longitudinal cohort & National study & - Reasons why women express & - to allow someone else to feed & Large sample \\
\hline & & $n=3606$ & $\begin{array}{l}\text { - Amount and prevalence of milk } \\
\text { expression }\end{array}$ & - maternal employment & $\begin{array}{l}\text { Not nationally representative } \\
\text { Participants older, more likely to } \\
\text { be educated, white, employed, } \\
\text { higher income }\end{array}$ \\
\hline & & $2005-2007$ & - Associated socio-demographic factors & - to have an emergency milk supply & \\
\hline & & from IFPS ॥ & & - no previous breastfeeding experience & \\
\hline & & & & - geographic location (Midwest Vs. West) & \\
\hline & & & & - embarrassed to breastfeed in public & \\
\hline \multirow[t]{2}{*}{$\begin{array}{l}\text { Buckley } 2009 \\
\text { USA [33] }\end{array}$} & Focus groups & Washington, DC & $\begin{array}{l}\text { - Ascertain lactation consultant's beliefs } \\
\text { and experiences re. impact of breast } \\
\text { pumps on breastfeeding practice }\end{array}$ & $\begin{array}{l}\text { - Technological birth contributes to } \\
\text { technological breastfeeding }\end{array}$ & $\begin{array}{l}\text { Exploration of professional } \\
\text { attitudes to change in feeding } \\
\text { practice -no previous exploration } \\
\text { of this area }\end{array}$ \\
\hline & & $n=12$ & & $\begin{array}{l}\text { - Engorgement, plugged ducts, to increase } \\
\text { supply, to stimulate the let-down reflex, to } \\
\text { pull out inverted nipples. }\end{array}$ & Small sample size \\
\hline
\end{tabular}


Table 3 Studies exploring reasons women express (Continued)

\begin{tabular}{|c|c|c|c|c|c|}
\hline & & Lactation consultants & & - Return to work & Volunteer participants \\
\hline & & Purposeful sampling & & $\begin{array}{l}\text { - Measuring milk, diminished confidence } \\
\text { in ability to provide enough milk }\end{array}$ & Date of study not indicated \\
\hline \multirow[t]{11}{*}{$\begin{array}{l}\text { Clemons \& Amir } \\
2010 \text { Australia [5] }\end{array}$} & \multirow[t]{11}{*}{ Cross-sectional } & State-wide study, Victoria & $\begin{array}{l}\text { - Prevalence of breast milk } \\
\text { expression }\end{array}$ & - Premature baby/sick mother or baby & Large study \\
\hline & & $n=903$ & $\begin{array}{l}\text { - Demographic characteristics of } \\
\text { women who express, why and } \\
\text { how they do it }\end{array}$ & - Attachment problems/not drinking well & $\begin{array}{l}\text { Possible selection bias (members } \\
\text { of } A B A \text { ) }\end{array}$ \\
\hline & & 2008 & $\begin{array}{l}\text { - Women's experience of using } \\
\text { breast pumps }\end{array}$ & - Advised & $\begin{array}{l}\text { Timing of questionnaire, possible } \\
\text { recall bias }\end{array}$ \\
\hline & & \multirow{8}{*}{$\begin{array}{l}\text { Online questionnaire sent to } \\
\text { Australian Breastfeeding } \\
\text { Association (ABA) members } \\
\text { who had an email address }\end{array}$} & & - Not enough milk/To store extra milk & \\
\hline & & & & - Nipple pain & \\
\hline & & & & - Engorged breasts/mastitis & \\
\hline & & & & - So someone else can feed baby & \\
\hline & & & & - Maternal work & \\
\hline & & & & - Just to try it out & \\
\hline & & & & - To allow mother to drink alcohol & \\
\hline & & & & - Uncomfortable breastfeeding in public & \\
\hline \multirow{5}{*}{$\begin{array}{l}\text { Geraghty et al. } \\
2012 \text { USA [29] }\end{array}$} & \multirow{5}{*}{$\begin{array}{l}\text { Prospective } \\
\text { longitudinal cohort }\end{array}$} & Cincinnati & - Duration of breast milk feeding & - Planned return to work by 6 months & Prospective design \\
\hline & & $n=60$ & $\begin{array}{l}\text { - Describe who commences } \\
\text { expressing early }\end{array}$ & & Small study \\
\hline & & 2004-2007 & & & $\begin{array}{l}\text { Recruitment of women who planned } \\
\text { to breastfeed for } 6 \text { months or more }\end{array}$ \\
\hline & & recruited face to face & & & $\begin{array}{l}\text { Mothers recruited for study knew } \\
\text { they were going to be assisted to } \\
\text { pump and may have been more } \\
\text { likely to be comfortable with this. }\end{array}$ \\
\hline & & & & & $\begin{array}{l}\text { Possible introduction of bias as } \\
\text { weekly collection of breast milk } \\
\text { was initiated at } 1 \text { week by research } \\
\text { nurse using an electric breast pump }\end{array}$ \\
\hline
\end{tabular}


and allowing the baby to be fed by someone other than his/her mother $[2,3,34,37]$. Women express in order to return to paid work $[3,5,38]$. Those who are in paid employment are more likely to express their milk when there are flexible work arrangements and designated places to express $[39,40]$. In addition to women who are in paid employment expressing milk, women who have a high income are also more likely to do so [3].

\section{Impact of expressing on breastfeeding outcomes}

There have been contradictory reports regarding the association between expressing breast milk and the success and duration of breastfeeding (Table 4). Some studies suggest that expressing to feed (as opposed to breastfeeding solely at the breast) in the early postpartum period is associated with shorter duration of breastfeeding $[1,41]$, while others have found the reverse $[42,43]$. Binns et al. report on trends in the expression of breastmilk and conclude "The appropriate use of expressed breastmilk allows a mother to achieve six months of exclusive breastfeeding while giving her more options with regards to paid work or study and the management of breastfeeding difficulties"[2] (Page 8). Women who fed at the breast only were found by Schwartz et al. to breastfeed for longer [41] and Chapman et al. reported that expressing did not improve milk volumes or duration of breastfeeding [44]. On the other hand, Win et al. in Perth, Australia, explored the association between expressing and the duration of breastfeeding and reported that mothers who expressed were more likely to be breastfeeding at six months than those who didn't express [45].

Studies that looked at duration of breast milk feeding have had differing outcomes. Ortiz et al. explored the duration of breast milk expression for women allocated to a lactation program which provided equipment and support for expressing. Findings indicated that these women were more likely to breast milk feed for longer than those who did not receive such support [39]. Geraghty et al. found that mothers who fed solely at the breast, particularly in the early weeks postpartum, were more likely to breast milk feed for longer than women who had combined breastfeeding with expressing [1].

\section{Implications for maternal health}

Breast pain and nipple trauma have been associated with expressing [5,29]; they contribute to maternal discomfort and distress, and nipple trauma is known to be associated with the development of mastitis [46]. While Thorley identifies compromised mother/infant skin-to-skin contact and bonding as a result of expressing [23], Johnson et al. call breast pumping liberating, giving the mother a means to "... negotiate some independence and manage the demands of breastfeeding" [34] (p. 900). These authors suggest that expressing may facilitate maternal independence, and give the mother freedom from the demands of her baby [34].

Considering the paucity of discussion in the literature, it appears that the implications of expressing on maternal mental health warrants attention.

\section{Other implications of expressing}

A range of other possible outcomes of breast milk expression bear consideration and can be seen in Table 5 . The additional handling involved in the expression, storage and subsequent bottle feeding of expressed milk creates additional risks for infection in the infant, as discussed and illustrated visually by Geraghty [25]. Breast milk, frozen and fed later loses vitamin content, and, like infant formula, it is at risk of contamination, as it is subject to more handling through the process of preparation [47]. Freezing, defrosting and reheating and microwaving all have the potential to compromise milk quality and safety $[48,49]$.

The infant fed from a bottle, regardless of the type of milk, is deprived of the benefits of self-regulation of intake associated with breastfeeding, which may increase the risk of subsequent childhood obesity [50,51]. Orofacial implications include the risk of dental caries associated with the use of a teat [52] and orthodontic problems associated with not breastfeeding [53].

\section{Discussion}

Although there is some commentary about an increase in breast milk expressing in the literature, actual measurement of the phenomena is quite limited. In addition, expressing breast milk is anecdotally less common in countries where there are more generous maternity leave provisions in terms of length of financial support, but there is limited evidence in the literature to support this. Two studies, one in Australia and the other in Singapore provide the only data actually documenting an increase in expressing over time $[2,6]$. Other authors discuss the prevalence of expressing and describe a preponderance of the practice [1-6,27]. This suggests that breast milk feeding solely at the breast is actually quite rare, at least in the developed world. Some breast milk expressing deserves consideration as incidental, something a mother might do only on occasion, for example when she needs to go out without her baby, when introducing infant cereal, when the infant is ill or unable to attach or is refusing the breast. We know that expressing breast milk has become more common, clarification of the amount, the proportion and the frequency of expressing and breast milk feeding is necessary before we can properly explore the implications of this relatively unexplained shift away from the breast. 
Table 4 Impact of expressing on breastfeeding outcomes

Author, year, Design Location, participants, year of

country study and recruitment

Study aims and outcome

Results

Strengths/Limitations

Chapman

Hartford, Connecticut

measures

et al. 200

Effects of expressing before the

USA [45]

$n=60$

- on early milk transfer

1997-1998

- on subsequen

breastfeeding duration

Convenience sample 8-24 hours post Caesarean Section

$\begin{array}{lll}\text { Schwartz } & \text { Prospective } & \text { Detroit, Ann Arbor and } \\ \text { et al. 2002 } & \text { cohort } & \text { Southfield, Michigan and Omaha, }\end{array}$

Nebraska

- Determine demographic,

USA [42]

$n=946$

behavioural and clinical factors associated with weaning from breast in the first 12 weeks

- No significant difference in milk transfer or breastfeeding duration between women who expressed breast milk and those who did not.

- Primiparous women in pumping group breastfed for 5 months less than those in control group but this finding was not statistically significant.

Only women who had a caesarean section

Study underpowered for primiparous women

- Michigan women $(n=711)$ who expressed breast milk were 3 times more likely to wean than those who didn't (Hazard Ratio: 3.0 95\% Cl 1.3,6.7)

- Nebraska women $(n=235)$ showed Only measured to 12 weeks no association between pumping and weaning (HR: 0.6, 95\% Cl 0.3,1.5)

1994-1998

Recruitment:

Michigan - at birth centre orientation

Nebraska - on maternity leave application to large company

Ortiz 2004

Clinical audit Burbank, California

$$
n=462
$$

1993-1999

Antenatal recruitment in workplace

\section{$\begin{array}{lll}\text { Geraghty } & \text { Retrospective } & \text { Cincinnati, Ohio } \\ \text { et al. 2005 } & \text { cohort }\end{array}$ et al. 2005} USA [1]

$$
n=346
$$

Measure breast pump use

Identify relationships between breast pump use and:

- singleton vs. multiple pregnancy
Duration of breast milk feeding

- 98\% (452/462) breastfeeding initiation - 74\% (246/332) expressed milk until infant at least 6 months

- 24\% (81/332) expressed milk unti infant at least 12 months

- Mean age of infants at maternal cessation of pumping at work 6.3 months

Of breast milk feeding mothers:

- 10\% (24/346) breastfed exclusively for a minimum of 6 months
Non-representative sample

Michigan group were recruited from an alternative birthing centre and were significantly more likely to be older than 30 years, have a bachelor's degree, have 3 or more children and have had a vaginal birth

Large study over 4.5 years

Limited differentiation between breastfeeding and expressing / breast milk feeding

No information re any other infant feeding/ exclusivity of breast milk feeding

No consideration of options in the workplace to breastfeed at the breast

Large sample size

Breastfeeding / breast milk feeding

clearly differentiated 


\begin{tabular}{|c|c|c|c|c|c|}
\hline & & & & $\begin{array}{l}-16 \%(55 / 346) \text { breastfed exclusively } \\
\text { for duration of their breast milk } \\
\text { feeding }\end{array}$ & $\begin{array}{l}\text { Periodic reports re. proportion of expressing } \\
\text { versus breastfeeding (at } 1 \text { day, } 3 \text { days, } \\
2 \text { weeks and monthly until } 6 \text { months) }\end{array}$ \\
\hline & & \multirow[t]{6}{*}{$\begin{array}{l}\text { Random selection Postal } \\
\text { recruitment when infants were } \\
\text { between } 2 \text { and } 3 \text { years old }\end{array}$} & - gestation at birth & $\begin{array}{l}-77 \%(182 / 236) \text { expressed at some } \\
\text { time in first } 6 \text { months }\end{array}$ & \multirow[t]{6}{*}{$\begin{array}{l}\text { Retrospective data, possible recall bias as } \\
\text { participants were recruited } 2 \text { or more years } \\
\text { post birth }\end{array}$} \\
\hline & & & - breastfeeding outcomes & $\begin{array}{l}\text { - 59\% (140/236) ceased breast milk } \\
\text { feeding by } 6 \text { months }\end{array}$ & \\
\hline & & & & $\begin{array}{l}\text { Of the } 140 \text { women who had ceased } \\
\text { breast milk feeding by } 6 \text { months, at } \\
\text { the time point just prior to exclusive } \\
\text { formula feeding: }\end{array}$ & \\
\hline & & & & $\begin{array}{l}\text { - } 76 \%(106 / 140) \text { were either expressing } \\
\text { exclusively or combining expressing } \\
\text { with breastfeeding }\end{array}$ & \\
\hline & & & & - 24\% (34/140) were breastfeeding & \\
\hline & & & & $\begin{array}{l}\text { Early breastfeeding associated with a } \\
\text { longer duration of breast milk feeding }\end{array}$ & \\
\hline \multirow[t]{5}{*}{$\begin{array}{l}\text { Win et al. } \\
\text { 2006 Australia } \\
\text { [55] }\end{array}$} & $\begin{array}{l}\text { Prospective } \\
\text { cohort }\end{array}$ & Perth, Western Australia & $\begin{array}{l}\text { - Investigate association between } \\
\text { breast milk expression and } \\
\text { breastfeeding duration }\end{array}$ & $\begin{array}{l}\text { - Mothers who expressed at least } \\
\text { once more likely to be breastfeeding } \\
\text { at } 6 \text { months (RR: } 0.71,95 \% \text { Cl 0.52,0.98) }\end{array}$ & Prospective design assisting recall \\
\hline & & PIFS ॥ & & & Ever "expressed" / "any" breastfeeding \\
\hline & & $\mathrm{n}=587$ & & & ? lower socio economic bias \\
\hline & & 2002-03 & & & No account of frequency of expressing \\
\hline & & Recruited in hospital at birth. & & & \\
\hline \multirow[t]{4}{*}{$\begin{array}{l}\text { Meehan et al. } \\
2008 \text { USA [43] }\end{array}$} & $\begin{array}{l}\text { Quasi- } \\
\text { experimental }\end{array}$ & Los Angeles, California & $\begin{array}{l}\text { - Evaluation of program to } \\
\text { facilitate breastfeeding for low } \\
\text { income mothers }\end{array}$ & $\begin{array}{l}\text { - Electric pump loan associated with } \\
\text { more breastfeeding at } 6 \text { months. } \\
\text { Mothers loaned a breast pump } 5.5 \\
\text { times more likely to than those who } \\
\text { hadn't received one to not have } \\
\text { requested formula by } 6 \text { months }\end{array}$ & $\begin{array}{l}\text { Limited reliability of proxy measurement to } \\
\text { assess breast milk feeding prevalence or duration }\end{array}$ \\
\hline & & $n=208$ & $\begin{array}{l}\text { - Maternal request for formula from } \\
\text { WIC program used as proxy } \\
\text { measurement to give indication of } \\
\text { partial breastfeeding }\end{array}$ & (OR: 5.5, 95\% Cl 2.0,15.1) & $\begin{array}{l}\text { No differentiation between breastfeeding and } \\
\text { breast milk feeding }\end{array}$ \\
\hline & & 2001 & & & \\
\hline & & $\begin{array}{l}\text { Breast pump loan program for } \\
\text { low income Women with } \\
\text { Children (WIC) recipients }\end{array}$ & & & \\
\hline \multirow[t]{2}{*}{$\begin{array}{l}\text { Fein } 2008 \\
\text { USA [41] }\end{array}$} & $\begin{array}{l}\text { Prospective } \\
\text { cohort }\end{array}$ & National & $\begin{array}{l}\text { - Examine strategies used to } \\
\text { combine work and breastfeeding }\end{array}$ & $\begin{array}{l}\text { Median duration of breast milk feeding } \\
\text { associated with workplace practices: }\end{array}$ & Large National study \\
\hline & & $\mathrm{n}=810$ & & & Prospective design \\
\hline
\end{tabular}

Investigate association between reast milk expression and breastfeeding duration

Maternal request for formula from WIC program used as proxy measurement to give indication of combine work and breastfeeding
- 16\% (55/346) breastfed exclusively

$-77 \%(182 / 236)$ expressed at some 59\% (140/236) ceased breast milk eding by 6 months

$-76 \%(106 / 140)$ were either expressing ding expressing

- 24\% (34/140) were breastfeeding

who expressed at least (ikely to be breastfeeding

No differentiation between breastfeeding and breast milk feeding 
Table 4 Impact of expressing on breastfeeding outcomes (Continued)

\begin{tabular}{|c|c|c|c|c|c|}
\hline & & & $\begin{array}{l}\text { - Identify strategies associated } \\
\text { with enhanced breastfeeding } \\
\text { intensity/longer duration }\end{array}$ & & \\
\hline & & $2005-2007$ & & $\begin{array}{l}\text { - expressing and breastfeeding } \\
\text { ( } 32.4 \text { weeks) }(n=75)\end{array}$ & Questionnaire design with 7 day recall \\
\hline & & from IFPS ॥ & & $\begin{array}{l}\text { - breastfeed at the breast only } \\
(31.4 \text { weeks })(n=250)\end{array}$ & $\begin{array}{l}\text { No description of feeding method away } \\
\text { from workplace }\end{array}$ \\
\hline & & $\begin{array}{l}\text { Recruitment via postal } \\
\text { questionnaire in late pregnancy }\end{array}$ & & - expressing only (26.3 weeks) $(n=75)$ & $\begin{array}{l}\text { Older, less educated, low income and women } \\
\text { from racial/ethnic minority groups } \\
\text { underrepresented }\end{array}$ \\
\hline & & & & $\begin{array}{l}\text { - neither breastfeeding or expressing } \\
(14.3 \text { weeks })(n=128)\end{array}$ & \\
\hline \multirow[t]{5}{*}{$\begin{array}{l}\text { Clemons \& } \\
\text { Amir 2010 } \\
\text { Australia [5] }\end{array}$} & $\begin{array}{l}\text { Cross- } \\
\text { sectional }\end{array}$ & State-wide, Victoria & $\begin{array}{l}\text { - Prevalence of breast milk } \\
\text { expression }\end{array}$ & $\begin{array}{l}\text { - } 27 \%(218 / 903) \text { indicated that } \\
\text { expressing had allowed them to } \\
\text { breastfeed for longer }\end{array}$ & Large study \\
\hline & & $n=903$ & $\begin{array}{l}\text { - Demographic characteristics of } \\
\text { women who express, why and } \\
\text { how they do it }\end{array}$ & & Possible selection bias (members of $A B A$ ) \\
\hline & & 2008 & $\begin{array}{l}\text { - Women's experience of using } \\
\text { breast pumps }\end{array}$ & & Timing of questionnaire, possible recall bias \\
\hline & & online questionnaire & & & \\
\hline & & $\begin{array}{l}\text { ABA members with internet } \\
\text { addresses }\end{array}$ & & & \\
\hline \multirow[t]{4}{*}{$\begin{array}{l}\text { Dabritz et al. } \\
2010 \text { USA [56] }\end{array}$} & $\begin{array}{l}\text { Retrospective } \\
\text { cohort }\end{array}$ & Yolo County, California & $\begin{array}{l}\text { - Assess relationship between } \\
\text { maternal experience in hospital } \\
\text { and any breastfeeding at six months }\end{array}$ & $\begin{array}{l}\text { - Almost exclusive breastfeeding at } \\
6 \text { months associated with not using a } \\
\text { breast pump in hospital } 77 \% \text { ( } 93 / 121) \\
\text { compared to 21\% (25/121) who did } \\
\text { use a pump in hospital (OR: } 0.695 \% \\
\text { Cl 0.3,1.0) }\end{array}$ & $\begin{array}{l}\text { Differentiation between breastfeeding and breast milk } \\
\text { feeding unclear }\end{array}$ \\
\hline & & $n=382$ & & & \\
\hline & & 2006-07 & & & $\begin{array}{l}\text { Possible recall bias - interviews 6-9 months } \\
\text { after birth }\end{array}$ \\
\hline & & $\begin{array}{l}\text { Recruited in community after } \\
\text { birth - } 8 \text { months }\end{array}$ & & & \\
\hline \multirow[t]{3}{*}{$\begin{array}{l}\text { Hornbeak } \\
\text { et al. } 2010 \\
\text { Singapore [6] }\end{array}$} & $\begin{array}{l}\text { Retrospective } \\
\text { cohort }\end{array}$ & Singapore & $\begin{array}{l}\text { - Record prevalence and patterns } \\
\text { of breastfeeding in Singaporean } \\
\text { Chinese mothers }\end{array}$ & $\begin{array}{l}\text { - Breast milk feeding initiation and } \\
\text { duration increased over time and were } \\
\text { independently associated with higher } \\
\text { maternal education, increased milk } \\
\text { expression and complementary feeding }\end{array}$ & $\begin{array}{l}\text { Large representative sample of Chinese } \\
\text { Singaporean mothers }\end{array}$ \\
\hline & & $n=3009$ & & $\begin{array}{l}\text { Changes between } 2000-01 \text { and 2006- } \\
\text { 08: }\end{array}$ & $\begin{array}{l}\text { Possible recall bias - recruitment 6-72 months } \\
\text { after birth }\end{array}$ \\
\hline & & $2006-2008$ & & $\begin{array}{l}\text { Infant formula feeding } 31 \%(66 / 210) \\
\text { to } 18 \%(118 / 656)\end{array}$ & Gestational age not indicated \\
\hline
\end{tabular}


Table 4 Impact of expressing on breastfeeding outcomes (Continued)

\begin{tabular}{|c|c|c|c|c|c|}
\hline & & $\begin{array}{l}\text { Recruited mothers of 6-72 month } \\
\text { Chinese Singaporean children } \\
\text { through STARS }\end{array}$ & & $\begin{array}{l}\text { Breast milk feed initiation } 69 \% \\
(144 / 210) \text { to } 82 \%(538 / 656)\end{array}$ & \\
\hline & & Mailed invitation & & $\begin{array}{l}\text { Expressed breast milk } 9 \%(18 / 210) \text { to } \\
18 \%(118 / 656)\end{array}$ & \\
\hline & & & & $\begin{array}{l}\text { Combination feeding } 26 \%(54 / 210) \text { to } \\
41 \%(269 / 656)\end{array}$ & \\
\hline \multirow[t]{5}{*}{$\begin{array}{l}\text { Geraghty } \\
\text { et al. 2012 } \\
\text { USA [29] }\end{array}$} & $\begin{array}{l}\text { Prospective } \\
\text { cohort }\end{array}$ & Cincinnati, Ohio & $\begin{array}{l}\text { - Determine who expresses their } \\
\text { milk by end of } 4 \text { weeks and how } \\
\text { long they continue feeding }\end{array}$ & $\begin{array}{l}\text { - Milk expression common in first } \\
\text { month postpartum }\end{array}$ & Prospective design \\
\hline & & $n=60$ & & $\begin{array}{l}\text { - Milk expression by } 4 \text { weeks did not } \\
\text { significantly influence duration of } \\
\text { breast milk feeding }\end{array}$ & $\begin{array}{l}\text { Clear differentiation between breastfeeding } \\
\text { and breast milk feeding }\end{array}$ \\
\hline & & 2004-2007 & & & $\begin{array}{l}\text { Recruitment of women who planned to } \\
\text { breastfeed for } 6 \text { months or more }\end{array}$ \\
\hline & & $\begin{array}{l}\text { Participants enrolled in a research } \\
\text { human milk bank recruited at } \\
\text { home in first week postpartum }\end{array}$ & & & $\begin{array}{l}\text { Mothers recruited for study knew they were } \\
\text { going to be assisted to pump and may have } \\
\text { been more likely to be comfortable with this. }\end{array}$ \\
\hline & & & & & $\begin{array}{l}\text { Possible introduction of bias as weekly collection of } \\
\text { breast milk was initiated at } 1 \text { week by research nurse } \\
\text { using an electric breast pump }\end{array}$ \\
\hline
\end{tabular}


Table 5 Other implications of expressing

\begin{tabular}{|c|c|c|c|c|c|}
\hline $\begin{array}{l}\text { Author, } \\
\text { year, } \\
\text { country }\end{array}$ & Design & $\begin{array}{l}\text { Location, participants, year of } \\
\text { study and recruitment }\end{array}$ & Study aims and outcome measures & Results & Strengths/Limitations \\
\hline \multirow{5}{*}{$\begin{array}{l}\text { Clemons \& } \\
\text { Amir 2010 } \\
\text { Australia [5] }\end{array}$} & \multirow{5}{*}{$\begin{array}{l}\text { Cross } \\
\text { sectional }\end{array}$} & State-wide study, Victoria & - Prevalence of breast milk expression & \multirow{5}{*}{$\begin{array}{l}\text { - 17\% (126/737) experienced nipple pain } \\
\text { associated with pump use }\end{array}$} & Large study \\
\hline & & $n=903$ & $\begin{array}{l}\text { - Demographic characteristics of women } \\
\text { who express, why and how they do it }\end{array}$ & & $\begin{array}{l}\text { Possible selection bias (members of } \\
A B A \text { ) }\end{array}$ \\
\hline & & 2008 & $\begin{array}{l}\text { - Women's experience of using breast } \\
\text { pumps }\end{array}$ & & $\begin{array}{l}\text { Timing of questionnaire, possible } \\
\text { recall bias }\end{array}$ \\
\hline & & $\begin{array}{l}\text { Online questionnaire sent to } \\
\text { Australian Breastfeeding Association } \\
\text { (ABA) members who had an email } \\
\text { address }\end{array}$ & & & \\
\hline & & Baby any age & & & \\
\hline \multirow[t]{4}{*}{$\begin{array}{l}\text { Li et al. } \\
2010 \cup S A \\
{[49]}\end{array}$} & \multirow[t]{4}{*}{$\begin{array}{l}\text { Longitudinal } \\
\text { cohort }\end{array}$} & National study & $\begin{array}{l}\text { - Test infant ability to self-regulate intake } \\
\text { - compare active sucking (breastfeeding) } \\
\text { with passive feeding (EBM via bottle) }\end{array}$ & $\begin{array}{l}\text { - Infants bottle fed early more likely to empty } \\
\text { bottle/cup in late infancy }\end{array}$ & $\begin{array}{l}\text { Large national longitudinal study } \\
\text { Minimal reporting bias for } \\
\text { exposure and outcome }-7 \text { day } \\
\text { retrospective recall }\end{array}$ \\
\hline & & $n=1597$ & $\begin{array}{l}\text { - Complete empting of bottle or cup in } \\
\text { late infancy used to indicate self- } \\
\text { regulation }\end{array}$ & - bottle a totally different feeding mode & Multivariate analysis \\
\hline & & 2005-2007 & & & $\begin{array}{l}\text { Maternal report of feeding } \\
\text { behaviour/bottle emptying - report- } \\
\text { ing error possible }\end{array}$ \\
\hline & & from IFPS ॥ & & & \\
\hline \multirow[t]{4}{*}{$\begin{array}{l}\text { Li et al. } \\
2012[50]\end{array}$} & \multirow[t]{4}{*}{$\begin{array}{l}\text { Longitudinal } \\
\text { cohort }\end{array}$} & USA & $\begin{array}{l}\text { - Multi level analysis to estimate weight } \\
\text { gain } X \text { type of milk \& feeding mode at } \\
3,5,7 . \text { and } 12\end{array}$ & $\begin{array}{l}\text { - Among infants fed only breast milk, Breast } \\
\text { milk fed infants gained } 780 \mathrm{~g} \text { per month in the } \\
\text { first year compared with breastfed infants who } \\
\text { gained } 729 \mathrm{~g}\end{array}$ & $\begin{array}{l}\text { Large national longitudinal study } \\
\text { Minimal reporting bias for } \\
\text { exposure and outcome }-7 \text { day } \\
\text { retrospective recall }\end{array}$ \\
\hline & & $n=1899$ & & $\begin{array}{l}\text { - Possible association between bottle feeding } \\
\text { EBM and increased weight gain }\end{array}$ & \\
\hline & & IFPS || & & & \\
\hline & & 2005-2007 & & & \\
\hline \multirow[t]{6}{*}{$\begin{array}{l}\text { Geraghty } \\
\text { et al. 2012 } \\
\text { USA [28] }\end{array}$} & \multirow[t]{6}{*}{$\begin{array}{l}\text { Retrospective } \\
\text { cohort }\end{array}$} & Cincinnati, Ohio & $\begin{array}{l}\text { - Examination of methods of maternal } \\
\text { expression and infant consumption of } \\
\text { breast milk }\end{array}$ & $\begin{array}{l}\text { - All expressed, all babies fed some expressed } \\
\text { milk }\end{array}$ & $\begin{array}{l}\text { Limited other exploration of this } \\
\text { area }\end{array}$ \\
\hline & & $n=40$ & & 95\% (38/40) infants breastfed and EBM & Small size \\
\hline & & 2008 & & $37 \%(15 / 40)$ fed EBM same day & Retrospective data collection \\
\hline & & $\begin{array}{l}\text { Outpatients attending breastfeeding } \\
\text { clinic, recruited by mail }\end{array}$ & & $30 \%(12 / 40)$ fed EBM same week & Possible recall bias \\
\hline & & & & $25 \%(8 / 40)$ fed EBM 1 and 4 weeks later & \\
\hline & & & & $13 \%(5 / 40)$ fed EBM more than 4 weeks later & \\
\hline
\end{tabular}


Although concluding remarks in the 2011 Cochrane review identify the relative effectiveness of hand expressing and less expensive breast pumps [28], it is not surprising that regular scheduled expressing is associated with the use of electric breast pumps [3]. Hand expressing barely rates a mention in the literature about expressing breast milk, although breast pump use and ownership are commonly discussed $[2,31,54,55]$. Thorley describes breast pumps as a substitute for the skill of hand expression [23]. A recent paper from Flaherman et al. reports on an apparent positive effect of hand expressing when compared with bilateral electric pumping [30]. The authors discuss the possibility that hand expressing contributes to less awkwardness or embarrassment for the mother, who is more likely to be comfortable hand expressing than using a pump when others are present [30]. After the establishment of a mature milk supply however, a 2013 review of studies comparing different methods of milk expression [37], identifies several that found electric breast pumping to be more effective than any other method in terms of milk volume obtained [49,56,57]. The let-down reflex, a physiological response that is the process by which milk becomes available for the baby, can be inhibited by stressful situations such as embarrassment [58]. This may also be the case when unfamiliar equipment such as the breast pump is used. Suggestions of unquantifiable benefits associated with teaching hand expressing are made by Morton as she cautions against an "over-reliance on mechanical interventions" [59] (p. 276). Maternal confidence may be enhanced by a more relaxed early postpartum experience. Ease with the mechanics of breastfeeding may be fostered for the woman who has had some experience handling her breasts to obtain milk, as she will have done when hand expressing. The confidence attained by the handling and the achievement of actually expressing, as well as the visualisation of her milk may reinforce such confidence as she has expressed simply, with her own hands and without the complication of any additional mechanisation.

Women express breast milk because of doubt about the adequacy of their milk supply [36]. Many do so because of initial difficulties establishing breastfeeding $[2,3,5,27]$. Maternal return to work has been identified as another reason $[3,5,27]$. Workplaces which provide options such as on-site childcare, lactation breaks for expressing and/or breastfeeding foster longer term breast milk feeding [60]. Focus on breast expression facilities may however encourage maternal return to the workforce at the cost of other initiatives, or at the cost of broader social change to support women to spend more time with their infants and by implication, breastfeeding. Elevated BMI, cultural differences and embarrassment about breastfeeding in public all contribute to increasing breast milk expression rates [3,5,27,29,32,34].
Simple attribution of cause and effect is probably inadequate in any discussion of expressing and its impact on breastfeeding success and duration. Several authors appear to refer to 'any' expressing without specifying relative quantities or proportions of breast milk feeds given, from the breast or otherwise $[2,4,6]$.

Expressing may contribute to a parental focus on the measurement of breast milk. Such quantification of breast milk may undermine confidence about the adequacy of milk supply, and may be reflected in parental anxiety about not knowing how much milk the baby is obtaining when feeding directly from the breast [31].

\section{Conclusions}

This literature review has found limited evidence about the prevalence and outcomes of expressing breast milk amongst mothers of healthy term infants. Authors use a variety of definitions to describe the various infant feeding options, which limits our ability to make conclusions. The practice of expressing breast milk has increased along with the commercial availability of a range of infant feeding equipment. Expressing breast milk has become more common and introduces an opportunity for others to feed the baby. It could be argued that, for some families, breastfeeding has been reduced to a task, which is that of providing milk for the baby, quite possibly even beyond arm's length, something that anyone can do and potentially at the cost to the special relationship between a mother and her infant. The reasons for expressing have broadened and acquired complexity, while the outcomes of expressing, when they have been examined, are contradictory.

\section{Competing interests}

The authors declare that they have no competing interests.

\section{Authors' contributions}

HMJ undertook the literature review and wrote the first draft. All authors contributed intellectual input into revisions of the paper. All authors read and approved the final manuscript.

\section{Acknowledgements}

HMJ has a La Trobe University PhD scholarship. The authors received no funding for conducting and writing this review.

\section{Author details}

${ }^{1}$ Mother \& Child Health Research, La Trobe University, Melbourne, Victoria, Australia. ${ }^{2}$ Royal Women's Hospital, Parkville, Victoria, Australia. ${ }^{3}$ School of Nursing and Midwifery, La Trobe University, Bundoora, Victoria, Australia.

Received: 5 March 2013 Accepted: 13 November 2013

Published: 19 November 2013

\section{References}

1. Geraghty SR, Khoury JC, Kalkwarf HJ: Human milk pumping rates of mothers of singletons and mothers of multiples. J Hum Lact 2005, 21(4):413-420.

2. Binns CW, Win NN, Zhao Y, Scott JA: Trends in the expression of breastmilk 1993-2003. Breastfeed Rev 2006, 14(3):5-9. 
3. Labiner-Wolfe J, Fein SB, Shealy KR, Wang C: Prevalence of breast milk expression and associated factors. Pediatrics 2008, 122(2):S63-S68.

4. Shealy KR, Scanlon KS, Labiner-Wolfe J, Fein SB, Grummer-Strawn LM Characteristics of breastfeeding practices among US mothers. Pediatrics 2008, 122(2):S50-S55.

5. Clemons SN, Amir LH: Breastfeeding women's experience of expressing: A descriptive study. J Hum Lact 2010, 26(3):258-265.

6. Hornbeak DM, Dirani M, Sham WK, Li J, Young TL, Wong TY, Chong YS, Saw SM: Emerging trends in breastfeeding practices in Singaporean Chinese women: findings from a population-based study. Ann Acad Med Singapore 2010, 39:88-94.

7. Fildes V: Breasts, Bottles and Babies. Edinburgh: Edinburgh University Press; 1986.

8. Walker M: Breast pumps and other technologies. In Breastfeeding and Human Lactation. 4th edition. Edited by Riordan J, Wambach K. Sudbury, Massachusetts: Jones and Bartlett; 2010:379-423.

9. Kaneson 100th anniversary webpage. http://www.kaneson.co.jp/100th/index.html

10. Powerhouse Museum Collection Database - Breastpumps. http://www. powerhousemuseum.com/collection/database/search_tags.php? tag=breast+pumps

11. Green D, Moye L, Schreiner RL, Lemons JA: The relative efficacy of four methods of human milk expression. Early Hum Dev 1982, 6(2):153-159.

12. Breast Pump webpage. http://www.medelabreastfeedingus.com/products/ category/breast-pumps.

13. Ameda webpage - breastfeeding product list. http://www.breastfeeding.com/ breastfeeding-products.

14. Blum LM: From \$acred to disembodied motherhood. In At The Breast: Ideologies of Breastfeeding and Motherhood in the Contemporary United States. Boston: Beacon Press; 1999:19-62.

15. Jaeger MC, Lawson M, Filteau S: The impact of prematurity and neonatal illness on the decision to breast-feed. J Adv Nurs 1997, 25(4):729-737.

16. Da Silva OP, Knoppert DC, Angelini MM, Forret PA: Effect of domperidone on milk production in mothers of premature newborns: a randomized, double-blind, placebo-controlled trial. CMAJ 2001, 164(1):17-21.

17. Fewtrell MS, Loh KL, Blake A, Ridout DA, Hawdon J: Randomised, double blind trial of oxytocin nasal spray in mothers expressing breast milk for preterm infants. Arch Dis Child Fetal Neonatal Ed 2006, 91(3):F169-F174.

18. Aarts C, Kylberg E, Hörnell A, Hofvander Y, Gebre-Medhin M, Greiner T, Umeå U: How exclusive is exclusive breastfeeding? A comparison of data since birth with current status data. Int J Epidemio/ 2000, 29(6):1041-1046.

19. Hector DJ: Complexities and subtleties in the measurement and reporting of breastfeeding practices. Int Breastfeed J 2011, 6:5.

20. Geraghty SR, Rasmussen KM: Redefining "breastfeeding" initiation and duration in an age of breastmilk pumping. Breastfeed Med 2010, 5(3):135-137.

21. Moher D, Liberati A, Tetzlaff J, Altman DG, The Prisma Group: Preferred reporting items for systematic reviews and meta-analyses: The PRISMA statement. PLoS Med 2009, 6(7):e1000097.

22. Rasmussen KM, Geraghty SR: The quiet revolution: breastfeeding transformed with the use of breast pumps. Am J Public Health 2011 101(8):1356-1359.

23. Thorley V: The dilemma of breastmilk feeding. Breastfeed Rev 2011, 19(1):5-7.

24. Johnson S, Leeming D, Williamson I, Lyttle S: Maintaining the 'good maternal body': expressing milk as a way of negotiating the demands and dilemmas of early infant feeding. J Adv Nurs 2012, 69(3):590-599.

25. Geraghty SR: Photo album of expressed breastmilk. Breastfeed Med 2010, 6(6):433-434.

26. Geraghty SR, Sucharew $H$, Rasmussen KM: Trends in breastfeeding: it is not only at the breast anymore. Matern Child Nutr 2013, 9(2):180-187.

27. Geraghty SR, Davidson E, Tabangin M, Morrow A: Predictors of breastmilk expression by 1 month postpartum and influence on breastmilk feeding duration. Breastfeed Med 2012, 7(2):112-117.

28. Becker GE, Cooney F, Smith HA: Methods of milk expression for lactating women. Cochrane Database Syst Rev 2011, 7:12.

29. Ohyama M, Watabe $H$, Hayasaka Y: Manual expression and electric breast pumping in the first $48 \mathrm{~h}$ after delivery. Pediatr Int 2010, 52(1):39-43.

30. Flaherman VJ, Gay B, Scott C, Avins A, Lee KA, Newman TB: Randomised trial comparing hand expression with breast pumping for mothers of term newborns feeding poorly. Arch Dis Child-Fetal Neonatal Ed 2012 97(1):F18-F23.

31. Buckley K: A double-edged sword: lactation consultants' perceptions of the impact of breast pumps on the practice of breastfeeding. J Perinat Educ 2009, 18(2):13-22.
32. Leonard SA, Labiner-Wolfe J, Geraghty SR, Rasmussen KM: Associations between high prepregnancy body mass index, breast-milk expression, and breast-milk production and feeding. Am J Clin Nutr 2011, 93(3):556-563.

33. Amir LH, Donath SM: A systematic review of maternal obesity and breastfeeding intention, initiation and duration. BMC Pregnancy Childbirth 2007, 7:9.

34. Johnson S, Williamson I, Lyttle S, Leeming D: Expressing yourself: A feminist analysis of talk around expressing breast milk. Soc Sci Med 2009, 69(6):900-907

35. Bonuck KA, Trombley M, Freeman K, McKee D: Randomized, controlled trial of a prenatal and postnatal lactation consultant intervention on duration and intensity of breastfeeding up to 12 months. Pediatrics 2005, 116(6):1413-1426.

36. Dykes F, Williams C: Falling by the wayside: a phenomenological exploration of perceived breast-milk inadequacy in lactating women. Midwifery 1999, 15(4):232-246.

37. Flaherman VJ, Lee HC: "Breastfeeding" by feeding expressed mother's milk. Pediatr Clin North Am 2013, 60(1):227-246.

38. Fein SB, Mandal B, Roe BE: Success of strategies for combining employment and breastfeeding. Pediatrics 2008, 122(2):S56-S62.

39. Ortiz J, McGilligan K, Kelly P: Duration of breast milk expression among working mothers enrolled in an employer-sponsored lactation program. Pediatr Nurs 2004, 30(2):111-119.

40. Whaley SE, Meehan K, Lange L, Slusser W, Jenks E: Predictors of Breastfeeding Duration for Employees of the Special Supplemental Nutrition Program for Women, Infants, and Children (WIC). J Am Diet Assoc 2002, 102(9):1290-1293.

41. Schwartz K, Arcy HJS D, Gillespie B, Bobo J, Longeway M, Foxman B: Factors associated with weaning in the first 3 months postpartum. $J$ Fam Pract 2002, 51(5):439-444.

42. Meehan K, Harrison GG, Afifi AA, Nickel N, Jenks E, Ramirez A: The association between an electric pump loan program and the timing of requests for formula by working mothers in WIC. J Hum Lact 2008, 24(2):150-158.

43. Bai $Y$, Wunderlich S, Fly A: Predicting intentions to continue exclusive breastfeeding for 6 months: a comparison among racial/ethnic groups. Matern Child Health J 2011, 15(8):1257-1264.

44. Chapman DJ, Young S, Ferris AM, Perez-Escamilla R: Impact of breast pumping on lactogenesis stage II after cesarean delivery: a randomized clinical trial. Pediatrics 2001, 107(6):E94.

45. Win N, Binns C, Zhao Y, Scott J, Oddy W: Breastfeeding duration in mothers who express breast milk: a cohort study. Int Breastfeed J 2006, 1:28.

46. Amir LH, Garland S, Lumley J: A case-control study of mastitis: nasal carriage of Staphylococcus aureus. BMC Fam Pract 2006, 7:57.

47. Boo NY, Nordiah AJ, Alfizah H, Nor-Rohaini AH, Lim VKE: Contamination of breast milk obtained by manual expression and breast pumps in mothers of very low birthweight infants. J Hosp Infect 2001, 49(4):274-281.

48. Hurst N, Meier P, Riordan J: Breastfeeding the preterm infant. In Breastfeeding and human lactation. 4th edition. Edited by Riordan J, Wambach K. Sudbury, Massachusetts: Jones and Bartlett; 2010:425-470.

49. Garza C, Johnson CA, Harrist R, Nichols BL: Effects of methods of collection and storage on nutrients in human milk. Early Hum Dev 1982, 6(3):295-303.

50. Li R, Fein SB, Grummer-Strawn LM: Do infants fed from bottles lack selfregulation of milk intake compared with directly breastfed infants? Pediatrics 2010, 125(6):e1386-e1393.

51. Li R, Magadia J, Fein SB, Grummer-Strawn LM: Risk of bottle-feeding for rapid weight gain during the first year of life. Arch Pediatr Adolesc Med 2012, 166(5):431-436.

52. Harris R, Nicoll AD, Adair PM, Pine CM: Risk factors for dental caries in young children: a systematic review of the literature. Community Dent Health 2004, 21(1):71-85.

53. Emerich K, Wojtaszek-Slominska A: Clinical practice. Later orthodontic complications caused by risk factors observed in the early years of life. Eur J Pediatr 2010, 169(6):651-655.

54. Johns HM, Forster DA, Amir LH, McLachlan HL, Moorhead AM, Ford R, McEgan KM: In-hospital feeding of term infants - Baseline data of a prospective cohort study to explore the prevalence and outcomes of breast milk expressing and breast pump usage. J Paediatr Child Health 2012, 48:15 
55. Johns HM, Forster DA, Amir LH, Moorhead AM, McEgan KM, McLachlan HL: Infant feeding practices in the first $24-48 \mathrm{~h}$ of life in healthy term infants. Acta Paediatr 2013, 102(7):315-320.

56. Slusher T, Slusher IL, Biomdo M, Bode-Thomas F, Curtis BA, Meier P: Electric breast pump use increases maternal milk volume in African nurseries. J Trop Pediatr 2007, 53(2):125-130.

57. Slusher TM, Slusher IL, Keating EM, Curtis BA, Smith EA, Orodriyo E, Awori S, Nakakeeto MK: Comparison of maternal milk (breastmilk) expression methods in an African nursery. Breastfeed Med 2012, 7(2):107-111.

58. Brodribb W: Breastfeeding Managment in Australia. In East Malvern. 4th edition. Victoria: Australian Breastfeeding Association; 2012:13.

59. Morton J: The importance of hands. J Hum Lact 2012, 28:276-277.

60. Meek JY: Breastfeeding in the workplace. Pediatr Clin North Am 2001, 48(2):461-474

doi:10.1186/1471-2393-13-212

Cite this article as: Johns et al:: Prevalence and outcomes of breast milk expressing in women with healthy term infants: a systematic review. BMC Pregnancy and Childbirth 2013 13:212.

\section{Submit your next manuscript to BioMed Central and take full advantage of:}

- Convenient online submission

- Thorough peer review

- No space constraints or color figure charges

- Immediate publication on acceptance

- Inclusion in PubMed, CAS, Scopus and Google Scholar

- Research which is freely available for redistribution 